\title{
Optimal Parameters in Disinfestation of Brown Hom Mali 105 by Infrared Heating Machine
}

\author{
Chirawat Kansamrong ${ }^{\mathrm{a}}$, Sukangkana Talangkun ${ }^{\mathrm{a}^{*}}$ \\ ${ }^{a}$ Department of Industrial Engineering, Faculty of Engineering, Khon Kaen University, Khon Kaen, 40002, Thailand \\ *sukangkana@kku.ac.th
}

\begin{abstract}
The objective of this research was to design an infrared machine model and optimal parameters to eradicate rice weevil mingled in Brown Hom Mali Rice 105. The suitable condition for a removal of the rice weevil was determined by Design of Experiment (DOE) method. Three operation factors consist of heating temperature, thickness of a layer of rice and heating time. Experimental design by Design-Expert Version 7.0 program was used in generating experiments. The desired operation condition must exhibit 100 percent removal of rice weevil without harm on quality or alter both chemical and biological properties of brown rice. At a constant gap of $10 \mathrm{~cm}$ between infrared tube and adjustable base, the optimum condition was heating temperature of 100 degree Celsius, thickness of a layer of rice of $0.5 \mathrm{~cm}$ and 1.5 minutes heating time.
\end{abstract}

Keywords: Brown Hom Mali Rice 105, Rice weevil, Design Expert.

\section{Introduction}

The benefits of healthy lifestyle and healthy consumption habits have been well established. Currently, healthy lifestyle receives more attention and becoming widely interest. Brown Hom Mali Rice 105 contains more nutrition and antioxidant properties compared to milled rice. Bran contains nutrient (Dietary Fiber) which help prevent colon cancer and stomach cancer. It also prevents the absorption of saturated fats into the stomach. The Brown Hom Mali Rice 105 contains vitamins B1 that help prevent beriberi help in the process converts starch into energy and helps in the functioning of the nervous system. As a result,
Brown Hom Mali Rice 105 has increasing in consumption each year. However, due to Brown Hom Mali Rice 105 contains many nutrients, it attracted to rice weevil. If brown rice was not properly stored, rice weevil would deteriorate rice quality. This shortens storage time of any brown rice.

There are many insects that deteriorate rice quality such as Lesser grain borer, Siamese grain beetle, Angoumois grain mot, Rice weevil, Corn weevil and Red flour beetle. Using chemical method such as pesticides in disinfestation is normally used during storage in commercial rice mill plants. It is easy to use but disadvantage is that pesticide may residues in rice and in the long term this may cause an illness ${ }^{(1)}$. Therefore, non-chemical method is safer disinfestation method. One of promising technique is by using heat via infrared radiation. Infrared is the heat radiation with shot wavelength. The recently study showed that with proper operating condition, infrared prototype machine can eliminate 100 percent of rice weevil and does not affect the quality of the Hom Mali Rice 105 which increase rice storage time ${ }^{(2)}$. DOE is one of the statistical techniques in generating optimum result with minimum time and resources.

Therefore, this research aims to design an infrared machine prototype to eradicate rice weevil mingled with Brown Hom Mali rice 105. Full Factorial Design by Design-Expert Version 7.0 was used in generating experiments. After radiation, chemical and physical qualities of all rice samples were examined 


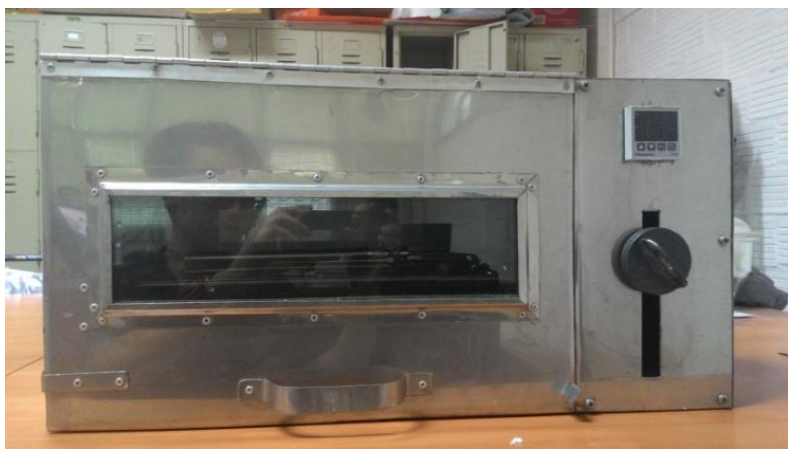

Fig 1. Micrographs of an infrared radiation machine.

\section{Materials and Methods}

\subsection{Materials}

The preparation of the rice weevil and rice weevil eggs. The amounts of 200 rice weevils were put in a plastic box containing 500 grams of Brown Hom Mali rice 105. The plastic box was covered with cotton cloth and stored at

(a) room temperature for 5 days. After that, eggs of rice weevils were collected from the box and stored at room temperature. Samples of Brown Hom Mali Rice 105 used in this study were supplied from a single local source (Baan Suan Supavata, Nakornratchasima province, Thailand).

(b) In each test, a sample unit consists of 30 grams of Brown Hom Mali Rice 105, 10 rice weevil eggs and 10 adult rice weevils. The moisture of Brown rice was measure and controlled within a range of 13 to14 percent ${ }^{(3)}$.

(c) An infrared heating machine was designed and built in house at the department of Industrial Engineering, Faculty of Engineering, Khon kaen University. A model machine is shown in Figure 1.

(d) The constant distance between an infrared lamp and the machine base was 10 centimeters.

\subsection{Methods}

(a) The sequence of experiment was generated using Full Factorial Design methods in Design-Expert Version 7.0. The three factors consisted of heating temperature, the thickness of Brown Hom Mali Rice 105 and heating time. Factors and levels are shown in Table 1. Twenty runs were tested with 3 repeats. Therefore, there were total of 60 runs.

(b) Analysis of the experiment by Main Effect Plot to decide the finer range of factor settings. After the analysis, it was found that new range of temperature was between 80 to 100 degrees Celsius, thickness of Brown
Table 1. The experimental factors.

\begin{tabular}{|c|c|c|c|c|}
\hline \multirow{2}{*}{ Factors } & \multicolumn{2}{|c|}{ Range } & \multirow{2}{*}{ Levels } & \multirow{2}{*}{ Symbol } \\
\hline & Min & Max & & \\
\hline Temperature $\left({ }^{\circ} \mathrm{C}\right)$ & 60 & 100 & $\begin{array}{l}5 \text { levels: } 60,70 \text {, } \\
80,90 \text { and } 100\end{array}$ & $\mathrm{~T}$ \\
\hline Thickness $(\mathrm{cm})$ & 0.5 & 2 & $\begin{array}{l}2 \text { levels: } 0.5 \text { and } \\
2\end{array}$ & $\mathrm{Th}$ \\
\hline Time ( min ) & 1 & 2 & 2 levels: 1 and 2 & $\mathrm{t}$ \\
\hline
\end{tabular}

Hom Mali Rice 105 was 0.5 to 1.50 centimeter and heating time remained unchanged. Then, the $3^{\mathrm{k}}$ factorial method by Design-Expert Version7.0 programs were used in generating of experiment runs. There were 32 runs with 2 repeated runs, therefore, there were total of 64 runs.

(c) Results were analyzed using Analysis of Variance (ANOVA) in order to find the optimal condition that can eradicate 100 percent of rice weevils and eggs.

(d) The optimal condition was repeatedly performed in order to confirm the result.

(e) After infrared test, rice samples were stored in room temperature. Chemical properties including moisture, ash, protein, fat, fiber and carbohydrates were then examined. Physical properties including weight and dimension were also examined.

\section{Results and Discussions}

\subsection{Analysis of the experiment by Main Effect Plot}

Fig. 2 shows main effect plot of heating temperature against the percentage of rice weevil mortality. It showed that amount of rice weevil mortality increases with increasing temperature. However, rice weevil mortality was less than 10 percent at temperature lower than 70

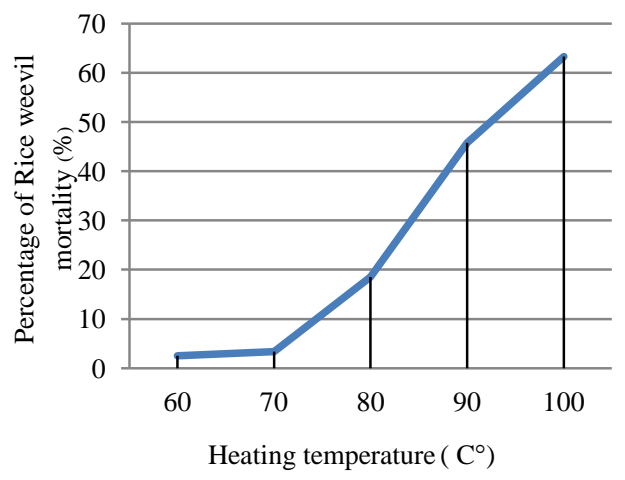

Fig 2. Graph shows the relationship between the percent of rice weevil mortality and the heating temperatures. 
degrees Celsius. Therefore, the new heating temperature range was set to be 80-100 degrees Celsius.

Fig 3 shows main effect plot of thickness of a rice layer against the percent of rice weevil mortality. It showed that amount of rice weevil mortality decreases with increasing thickness. Therefore the new thickness range was set to be $0.5-1.5 \mathrm{~cm}$ which exhibited greater than $10 \%$ of rice weevil mortality.

Figure 4 shows effect plots of heating time of a rice layer against amount of rice weevil death. It showed that amount of rice weevil mortality increases with increasing heating time. All conditions exhibit greater than $10 \%$ of rice weevil mortality. Therefore, the range of heating time remains unchanged.

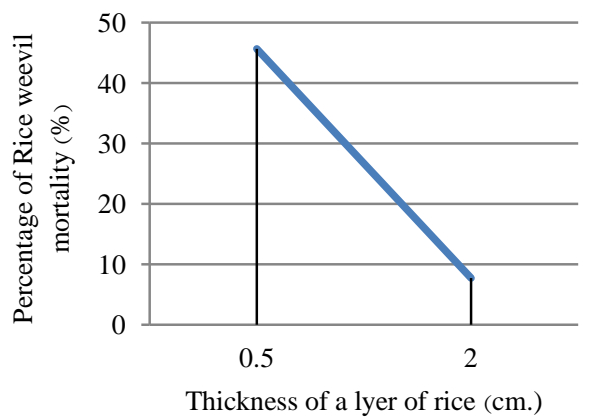

Fig 3. Graph shows the relationship between the percent of rice weevil mortality and the thickness of layer of rice.

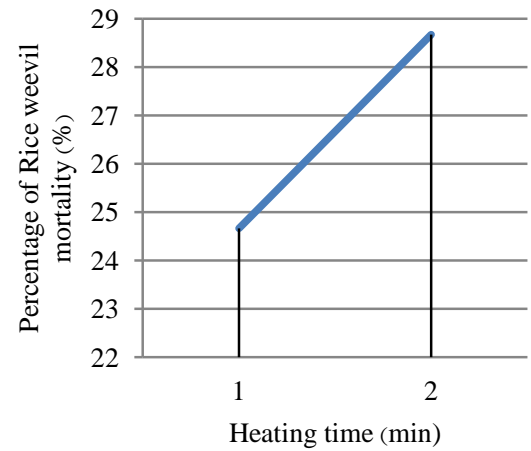

Fig 4. Graph shows the relationship between the percent of rice weevil mortality and the heating time.
Table 2. The $3^{\mathrm{k}}$ experimental factors and levels

\begin{tabular}{|l|c|c|c|c|}
\hline \multirow{2}{*}{ Factor } & \multicolumn{2}{|c|}{ Range } & \multirow{2}{*}{ Levels } & \multirow{2}{*}{ Symbol } \\
\cline { 2 - 3 } & Low & High & & \\
\hline Temperature $\left({ }^{\circ} \mathrm{C}\right)$ & 80 & 100 & $80,90,100$ & $\mathrm{~T}$ \\
\hline thickness $(\mathrm{cm})$ & 0.5 & 1.5 & $0.5,1.0,1.5$ & $\mathrm{Th}$ \\
\hline Time $(\mathrm{min})$ & 1 & 2 & $1,1.5,2$ & $\mathrm{t}$ \\
\hline
\end{tabular}

\subsection{Design an experiment by $3^{\mathrm{k}}$ factorial design method}

Analysis of the Main Effect in Figures 2-4 can be summarized trials in appropriate factors in Table 2. Using design and experiment by $3^{\mathrm{k}}$ factorial design method, there were 32 runs with 2 repeated runs, therefore, there were total of 64 runs. Results of 64 runs were then analyzed using ANOVA.

\subsection{Analysis of Variance}

Analysis of variance (ANOVA) which requires a p-value less than 0.05 indicates that the derived model is statistically significant and acceptable ${ }^{(4)}$. Hence, the overall model p-value (probability of error value) being less than 0.0001 double confirms that the model is very significant ${ }^{(5)}$ result in one or more factors that affect mortality of rice weevil. From Table 3, it is indicated that factors contributing to the death of rice weevil are the temperature and thickness of a layer of rice. Model of rice weevil mortality is showed in equation (1). Table 4 shows values of the determination coefficient $\mathrm{R}^{2}$ and Adj. $\mathrm{R}^{2}$ indicates the goodness of fit of the model. In this study, the determination coefficient $\mathrm{R}^{2}=0.868$ and the value of the adjusted determination coefficient adjusted $\mathrm{R}^{2}=0.845$ which is also high, indicates the high accuracy of the model. The percentage of rice weevil mortality (PRM) can be expressed as:

$\mathrm{PRM}=-103.645+2.073 \mathrm{~A}+14.212 \mathrm{~B}-0.639 \mathrm{C}-0.408 \mathrm{AB}$

$-0.008 A^{2}+9.602 B^{2}$

where $\mathrm{A}$ is heating temperature (degree Celsius) and $\mathrm{B}$ is thichness of a layer of rice $(\mathrm{cm})$.

The surface plot in Figure 5 can be obtained from equation (1). It was found that the death of rice weevil increases with increasing of temperature and decreasing of rice thickness. While heating time has no significant effect since the $\mathrm{p}$-value is greater than 0.05 . 
Table 3. Analysis result ANOVA death of the rice weevil.

\begin{tabular}{|c|c|c|c|c|c|c|}
\hline \multicolumn{7}{|c|}{ ANOVA for Response Surface Quadratic Model } \\
\hline \multicolumn{7}{|c|}{ Analysis of variance table [Partial sum of squares - Type III] } \\
\hline $\begin{array}{l}\text { Source of } \\
\text { variation }\end{array}$ & $\begin{array}{l}\text { Sum of } \\
\text { square }\end{array}$ & df & $\begin{array}{l}\text { Mean } \\
\text { square }\end{array}$ & $\begin{array}{c}F \\
\text { value }\end{array}$ & $P$-value & \\
\hline Model & 602.01 & 9 & 66.89 & $\begin{array}{c}38.7 \\
6\end{array}$ & $\begin{array}{c}< \\
0.0001\end{array}$ & significant \\
\hline A-temp & 93.44 & 1 & 93.44 & $\begin{array}{c}54.1 \\
5\end{array}$ & $\begin{array}{c}< \\
0.0001\end{array}$ & \\
\hline B-thick & 306.25 & 1 & 306.25 & $\begin{array}{c}177 . \\
47\end{array}$ & $\begin{array}{c}< \\
0.0001\end{array}$ & \\
\hline C-time & 9.00 & 1 & 9.00 & 5.22 & 0.0264 & \\
\hline $\mathrm{AB}$ & 100.04 & 1 & 100.04 & $\begin{array}{c}57.9 \\
7\end{array}$ & $\begin{array}{c}< \\
0.0001\end{array}$ & \\
\hline $\mathrm{AC}$ & 0.17 & 1 & 0.17 & 0.10 & 0.7572 & \\
\hline $\mathrm{BC}$ & 4.17 & 1 & 4.17 & 2.42 & 0.1262 & \\
\hline $\mathrm{A}^{\wedge} 2$ & 10.32 & 1 & 10.32 & 5.98 & 0.0178 & \\
\hline $\mathrm{B}^{\wedge} 2$ & 82.45 & 1 & 82.45 & $\begin{array}{c}47.7 \\
8\end{array}$ & $\begin{array}{c}< \\
0.0001\end{array}$ & \\
\hline $\mathrm{C}^{\wedge} 2$ & 0.32 & 1 & 0.32 & 0.19 & 0.6664 & \\
\hline Residual & 91.46 & 53 & 1.73 & & & \\
\hline $\begin{array}{c}\text { Lack of } \\
\text { Fit }\end{array}$ & 86.63 & 43 & 2.02 & 4.17 & 0.0098 & significant \\
\hline $\begin{array}{l}\text { Pure } \\
\text { Error }\end{array}$ & 4.83 & 10 & 0.48 & & & \\
\hline Total & 696.11 & 63 & & & & \\
\hline
\end{tabular}

Table 4. Results of regression analyzes of mortality rice weevil.

\begin{tabular}{|l|r|l|r|}
\hline Std. Dev. & $\mathbf{1 . 3 1 3 6 3 8 7 9 9}$ & R-Squared & $\mathbf{0 . 8 6 8 1 1 3 3 2 8}$ \\
\hline Mean & $\mathbf{2 . 3 2 8 1 2 5}$ & Adj R-Squared & $\mathbf{0 . 8 4 5 7 1 7 4 7 8}$ \\
\hline C.V. \% & $\mathbf{5 6 . 4 2 4 7 5 3 7 8}$ & Pred R-Squared & $\mathbf{0 . 8 0 3 6 9 3 9 1}$ \\
\hline PRESS & $\mathbf{1 3 6 . 1 3 2 1 3 9 1}$ & Adeq Precision & $\mathbf{2 2 . 7 7 6 1 2 1 9 8}$ \\
\hline Final Equation in Terms of Actual Factors: \\
Dead & $=$ \\
-103.6451613 & $*$ temperature \\
2.073476703 & $*$ thickness \\
14.21236559 & $*$ time \\
-0.639784946 & $*$ temperature * thickness \\
-0.408333333 & $*$ temperature * time \\
0.016666667 & $*$ thickness * time \\
-1.666666667 & $*$ temperature 2 \\
-0.008494624 & $*$ thickness 2 \\
9.602150538 & $*$ time 2 \\
0.602150538 & \\
\hline
\end{tabular}

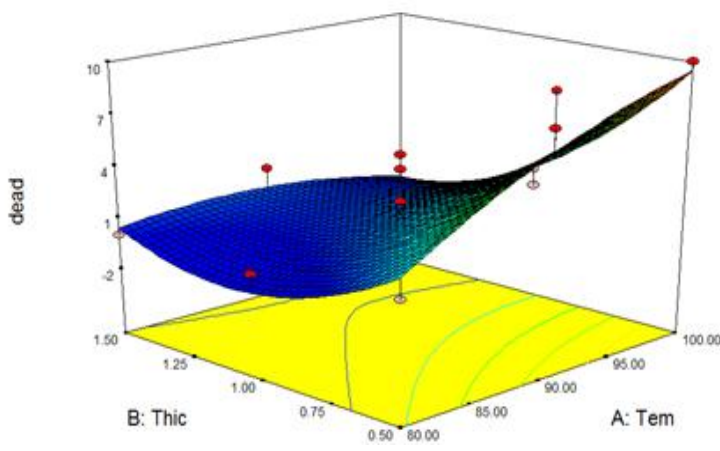

Fig. 5. Response Surface death of rice weevil between thickness and temperature.

\subsection{Optimal parameters}

There are two conditions that exhibited $100 \%$ mortality of rice weevil as listed in Table 5. However, the optimal condition was further considered the condition that gives best rice quality indicated from chemical analysis.

Table 6 shows results of chemical properties of rice in as-received condition and after Infrared radiation tests. The standard values also show as a comparison. It can be seen that amount of moisture, protein, fat, fiber slightly decrease, while ash and carbohydrate slightly increase. Results of changing in each property can be explained as below.

(a) Moisture; before infrared radiation was $13.5 \%$ and after infrared radiation is $13.2 \%$. The moisture content decreased $0.3 \%$ equivalent to $2.22 \%$ decreasing. Lower moisture content helps prolong in storage time.

(b) Protein; before infrared radiation was 7.45 grams and after infrared radiation was 7.27 grams. The protein content decreased by 0.18 grams equivalent to $2.47 \%$ decreasing. As a result, a protein that inhibits the absorption of water into the grain reduced short cooking time

(c) Fat; before infrared radiation was 2.64 grams and after infrared radiation was 2.42 grams. The fat content decreased by 0.22 grams equivalent to $8.33 \%$ decreasing. Reduction of fat reduces rancid.

Table 5. Factors that could eliminate rice weevil hundred percent and experimental results.

\begin{tabular}{|c|c|c|c|}
\hline \multirow{2}{*}{ Items } & \multicolumn{3}{|c|}{ factors } \\
\cline { 2 - 4 } & $\begin{array}{c}\text { temperature } \\
\left({ }^{\circ} \mathbf{c}\right)\end{array}$ & $\begin{array}{c}\text { thickness } \\
(\mathbf{c m} .)\end{array}$ & $\begin{array}{c}\text { time } \\
(\mathbf{m i n})\end{array}$ \\
\hline 1 & 90 & 0.5 & 2 \\
\hline 2 & 100 & 0.5 & 1.5 \\
\hline
\end{tabular}


Table 6. The comparison chemical quality between before and after infrared radiation

\begin{tabular}{|c|c|c|c|c|c|c|}
\hline Rice type & 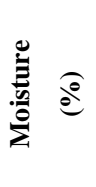 & 可 & $\vec{I}$ & $\sum_{\vec{D}}^{00}$ & जี & Oِ \\
\hline $\mathrm{BR}(\mathrm{std})^{(6)}$ & $13-14$ & $7.1-8.3$ & $1.6-2.8$ & $0.6-1.0$ & $1.0-1.5$ & $73-87$ \\
\hline $\mathrm{BR}(1)$ & 13.5 & 7.45 & 2.64 & 0.5 & 1.35 & 74.56 \\
\hline $\mathrm{BR}(2)$ & 13.1 & 7.33 & 2.47 & 0.5 & 1.29 & 75.31 \\
\hline $\mathrm{BR}(3)$ & 13.2 & 7.27 & 2.42 & 0.46 & 1.37 & 75.28 \\
\hline
\end{tabular}

Note

BRstd $=$ Brown Hom Mali Rice 105, a standard nutritional quality of rice.

BR1 = Brown Hom Mali Rice 105 before infrared radiation

$\mathrm{BR} 2$ = Brown Hom Mali Rice 105 after infrared radiation items 1 in table 5

$\mathrm{BR} 3$ = Brown Hom Mali Rice 105 after infrared radiation items 2 in table 5

(d) Fiber; before infrared radiation was 0.5 grams and after infrared radiation was 0.46 grams. Both before and after the infrared radiation was lower than the standard, the after infrared radiation was reduced to 0.04 grams equivalent to $8 \%$ decreasing.

(e) Ash; before infrared radiation was 1.35 grams and after infrared radiation was 1.37 grams. So 0.02 grams (1.48\% increased) of ash increased will help make better digestion.

(f) Carbohydrate; before infrared radiation was 74.56 grams and after infrared radiation was 75.28 grams. Carbohydrate increases $0.97 \%$ give higher amount of energy.

Table 7. Weight reduction of Brown Hom Mali Rice 105 before and after infrared radiation.

\begin{tabular}{|c|c|c|c|c|c|}
\hline \multicolumn{2}{|c|}{ average weight } \\
\hline before & after & $\%$ & before & after & \% \\
& & change & & & BR2 \\
& & -0.7 & 30.014 & & -0.66 \\
\hline 30.011 & 29.802 & & & 29.816 & \\
\hline
\end{tabular}

Table 8. Table 8 Grain dimension Jasmine brown rice 105 Standard

\begin{tabular}{|c|c|c|c|c|}
\hline $\begin{array}{c}\text { Rice Seed } \\
\text { Standard } \\
\text { (mm.) }\end{array}$ & $\begin{array}{c}\text { Before } \\
\text { infrared } \\
\text { radiation } \\
\text { (unit) }\end{array}$ & $\begin{array}{c}\text { Percent } \\
\text { (\%) }\end{array}$ & $\begin{array}{c}\text { After } \\
\text { infrared } \\
\text { radiation } \\
\text { (unit) }\end{array}$ & Percent \\
(\%)
\end{tabular}

Weight loss of sample after infrared radiation (IR No.2) is showed in Table 7. The average weight loss was approximately 0.198 grams equivalent to $0.66 \%$. This is due to the reduction of moisture, fat, fiber and protein. However, physical property was not altered by heating.

Table 8 shows grain dimension of brown Hom Mali rice 105 Standard. Again, dimension of grains was not altered by heating. The optimum condition was chosen using the shortest production time criteria, therefore, the optimum condition is condition No.2; infrared temp of $100^{\circ} \mathrm{C}$ (rice temp. about $75^{\circ} \mathrm{C}$ ), thickness of $0.5 \mathrm{~cm}$ and $1.5 \mathrm{~min}$ heating time.

\section{Conclusions}

The following conclusions can be drawn from the current study.

(a) The application of design of experiment in response surface methodology with $3^{\mathrm{k}}$ factorial design was used in generating operating conditions. Factors affected on rice weevil disinfestations were heating time and rice thickness determined by $\mathrm{p}$-value. The death of rice weevil increases with increasing of temperature and decreasing of rice thickness. 
(b) The prediction model can be expressed as $\mathrm{PRM}=-103.645+2.073 \mathrm{~A}+14.212 \mathrm{~B}-0.639 \mathrm{C}-0.408 \mathrm{AB}$ $-0.008 \mathrm{~A}^{2}+9.602 \mathrm{~B}^{2}$. The coefficient of determination (R2) was 0.868 .

(c) The optimum condition giving 100 percent of rice weevil mortality and shortest production time is; infrared temp of $100^{\circ} \mathrm{C}$ (rice temp. about $75^{\circ} \mathrm{C}$ ), thickness of $0.5 \mathrm{~cm}$ and time of $1.5 \mathrm{~min}$.

(d) After infrared radiation under an optimum condition, quality of rice was remains in the standard range. Weight loss after heating was approximately $0.66 \%$.

\section{References}

(1) Chuwit Sukprakarn and Phonthip Wisanthanon : "Productivity and control pests. Journal Of Agriculture" Vol. 22, pp 299-311, 2000

(2) Withaya Insorn : "The Development of Infrared Radiation in Disinfestations of the Organic Hom Mali Rice 105", Industrial Engineering Ubon Rajathanee university: Thailand, 2012

(3) Department of Foreign Trade : "Standard Rice and standard Thai Hom Mali Rice ( Thai edition )", 2003

(4) Baroutian S, Aroua MK, Abdul Raman AA and Nik Sulaiman NM.: "Potassium hydroxide catalyst supported on palm shell activated carbon for transesterification of palm oil", Fuel Process Technol, Vol. 91, pp 1378-1385, 2010

(5) Zahra Jeirani, Badrul Mohamed Jan, Brahim Si Ali, Ishenny Mohd. Noor, See Chun Hwa and Wasan Saphanuchart : "The optimal mixture design of experiments: Alternative method in optimizing the aqueous phase composition of a microemulsion", Chemometrics and Intelligent Laboratory Systems Journal, Vol.112, pp 1-7, 2012

(6) Juliano, B. O. and Bechtel, D. B. : Rice: Chemistry and Technology, pp.17-57, 1985 